\title{
PkM PEMANFAATAN POSYANDU LANSIA DI DESA SUKARAYA KECAMATAN PANCURBATU TAHUN 2017
}

\author{
SULAIMAN M.KM ${ }^{1)}$, ANGGRIANI Sst,Ft, M.KM ${ }^{2)}$ \\ Sekolah Tinggi Ilmu Kesehatan Siti Hajar \\ man_fisioterapi@yahoo.co.id ${ }^{1)}$ \\ anggriani.anggri1978@ gmail.com $^{2)}$
}

\begin{abstract}
ABSTRAK
Jumlah lanjut usia (lansia) semakin meningkat seiring keberhasilan pembangunan di Indonesia. Lansia memerlukan pemeliharaan kesehatan yang terjangkau untuk mengatasi masalah kesehatannya. Posyandu lansia merupakan alternatif sarana untuk memenuhi kebutuhan kesehatan tersebut. Pemanfaatan posyandu lansia di Desa Sukaraya Kecamatan Pancur Batu Kabupaten Deli Serdang masih sangat rendah. Tujuan dari Pengabdian Kepada Masyarakat ini adalah memberikan penyuluhan dan bimbingan pentingnya posyandu lansia terutama kepada lansia, keluarga lansia, kader posyandu serta pemangku kepentingan yang ada di Desa Sukaraya Kecamatan Pancurbatu. Sarana dan prasarana yang telah disediakan oleh pemerintah daerah dan desa dapat dimanfaatkan dengan baik oleh masyarakat Desa Sukaraya Hasil dari Pengabdian Kepada Masyarakat ini menunjukkan bahwa sebanyak 50\% responden memanfaatkan posyandu lansia. Diharapokan kader posyandu, keluarga lansia, serta pemangku kepentingan dapat turut berpartisipasi aktif dalam membantu pemanfaatan posyandu lansia.
\end{abstract}

Kata Kunci : Pemanfaaan, Posyandu Lansia

\begin{abstract}
Number of elderly (seniors) are increasing the success of development in Indonesia. Seniors need affordable health care to address their health problems. Elderly integrated service post is an alternative means to meet the health needs. Utilize elderly integrated service pos in Sukaraya village sub district Pancurbatu District Deli Serdang is still very low The purpose of Community Service is to provide counseling and guidance on the importance of elderly the integrated service post especially to elderly, elderly families, the cadres of the integrated service post and stakeholders in the region of the village of Pancurbatu subdistrict Sukaraya The facilities and infrastructure that have been provided by the local government and village can be utilized well by the people of Sukaraya The result showed that there were $50 \%$ of respondents utilize the elderly integrated service post. It is expected the cadres of the integrated service post, elderly families, and stakeholders can participate actively in helping the utilization of the integrated service post
\end{abstract}

Keywords: Utilization, integrated service post 


\section{Pendahuluan}

Lansia umumnya mengalami berbagai penyakit degeneratif akibat terjadinya penurunan fungsi biologis, psikologis, sosial, dan ekonomi. Perubahan ini akan memberikan pengaruh pada seluruh aspek kehidupan, termasuk kesehatannya. ${ }^{1}$

Pertambahan jumlah lansia di dunia berusia 60 tahun ke atas dua kali lipat, yaitu dari $11 \%$ di tahun 2006 menjadi $22 \%$ pada tahun 2050. Populasi lansia di dunia tahun 2006 sekitar 650 juta, akan mencapai 2 miliar pada tahun 2050. Pada negara-negara berkembang penduduknya akan mengalami penuaan yang jauh lebih cepat dari negara-negara maju $^{2}$

Berkaitan dengan status kesehatan pada lansia, saat ini pemerintah telah mencanangkan program peningkatan derajat kesehatan khusus lansia melalui posyandu lansia. Posyandu lansia merupakan perwujudan pelaksanaan program pengembangan dari kebijakan pemerintah melalui pelayanan kesehatan bagi lansia (posyandu), sebagai suatu forum komunikasi dalam bentuk peran serta masyarakat usia lanjut, keluarga, tokoh masyarakat dan organisasi sosial masyarakat dalam upaya peningkatan tingkat kesehatan secara optimal. ${ }^{3}$

Upaya pemanfaatan pelayanan posyandu lansia perlu mendapatkan perhatian serius dan menjadi bagian dari strategi dalam peningkatan kesejahteraan lansia melalui upaya promotif dan preventif atau yang biasa disebut paradigma sehat. Mengingat fisik lansia yang lemah sehingga mereka tidak dapat leluasa menggunakan sarana dan prasarana maka upaya pemanfaatan pelayanan posyandu lansia yaitu dengan menyediakan sarana dan fasilitas khusus bagi lansia. Hal ini dimaksudkan untuk memudahkan lansia melakukan aktivitasnya. Penyediaan sarana dan prasarana ini tentunya melibatkan peran serta masyarakat seperti tokoh masyarakat, keluarga, kader dan sebagainya. ${ }^{4}$

Penelitian Widjajono di Dusun Soragan Desa Ngestiharjo Kecamatan Kasihan Kabupaten Bantul tentang berbagai faktor yang berpengaruh terhadap partisipasi lansia dalam kegiatan posyandu plus, dapat dilihat bahwa tingkat partisipasi lansia cukup tinggi, dukungan keluarga dan pengetahuan tidak berpengaruh signifikan terhadap partisipasi tetapi motivasi, peranserta tokoh masyarakat dan pelayanan kesehatan petugas kesehatan berpengaruh secara signifikan terhadap partisipasi lansia. ${ }^{3}$

Penelitian

Mulyadi menggunakan desain kualitatif di Kota Pariaman menunjukkan bahwa faktor utama yang mendorong lansia memanfaatkan posyandu lansia adalah dorongan petugas kesehatan, kader, anak, teman sebaya dan tokoh masyarakat. Alasan lansia tidak memanfaatkan posyandu lansia antara lain adalah kurang percaya terhadap pelayanan yang diberikan oleh bukan tenaga dokter; tidak dapat meninggalkan pekerjaan; obat yang diberikan tidak dapat mengatasi masalah kesehatan mereka; anggapan kegiatan posyandu lansia hanya untuk lansia perempuan; pengalaman buruk anggota keluarga ketika memanfaatkan pelayanan kesehatan modern ${ }^{4}$

Rendahnya kunjungan lansia ke posyandu menyebabkan lansia kurang dapat memantau status kesehatannya karena lansia cenderung mengalami gejala penyakit degeneratif karena faktor fisik yang lemah. Padahal hal ini dapat dipantau atau dicegah apabila lansia 
rajin datang ke posyandu lansia. Kesehatan lansia yang karena kondisi fisik dan mentalnya tidak memungkinkan lagi untuk berperan aktif dalam beraktivitas, maka lansia perlu mendapat perhatian khusus terutama dari keluarga, kader maupun masyarakat di sekitarnya.

Pengabdian ini bertujuan untuk meningkatkan pemanfaatan posyandu lansia di wilayah kerja Desa Sukaraya Kecamatan Pancur Batu Tahun 2017

\section{Permasalahan Mitra}

Mengacu kepada butir analisis situasi di atas, ada beberapa permasalahan mitra yang harus diberikan solusinya agar permasalahan mitra dapat diselesaikan, diantara permasalahan tersebut adalah:

1. Lansia tidak memanfaatkan posyandu lansia antara lain adalah kurang percaya terhadap pelayanan yang diberikan oleh bukan tenaga dokter; tidak dapat meninggalkan pekerjaan; obat yang diberikan tidak dapat mengatasi masalah kesehatan mereka;

2. Anggapan kegiatan posyandu lansia hanya untuk lansia perempuan; pengalaman buruk anggota keluarga ketika memanfaatkan pelayanan kesehatan modern.

3. Tidak adanya dukungan keluarga bagi lansia

4. Kader posyandu yang cuek, kurang paham dan tidak memberikan simpati kepada lansia.

5. Toko masyarakat dan para pemangku kepentingan kurang mendukung kegiatan posyandu lansia.
Setelah melihat permasalahan yang di alami oleh mitra, perlu adanya gebrakan atau tindakan dari masyarakat sendiri. Untuk itu perlunya dilakukan penagbdian ini Desa Sukaraya Kecamatan pancurbtau Kabupaten Deli Serdang Sumatera Utara

\section{Metode Pelaksanaan}

Kegiatan Pengabdian Kepada Masyarakat ini dilakukan dengan memberikan penyuluhan kepada lansia, keluarga lansia, kader posyandu serta pemangku adat atau tokoh masyarakat di Desa Sukaraya Kecamatan Pancurbatu Kabupaten Deli Serdang. Langkahlangkah yang akan ditempuh dalam pengabdian adalah sebagai berikut:

i. Pemberian informasi kepada lansia akan pentingnya manfaat dari mengikuti posyandu lansia. Rentannya terkenanya penyakit bagi para lansia. Sehingga dengan mengikuti posyandu lansia ini lansia terhindar dari penyakitpenyakit yang kerap terjadi pada usia lanjut.

ii. Memberikan penyuluhan kepada keluarga lansia agar keluarga ikut berperan aktif dengan cara mengantar lansia ke tempat posyandu lansia, memberikan dukungan serta member motivasi.

3. Memeberikan penyuluhan kepada kader posyandu agar membuat startegi promosi lebih menarik agar lansia rajin hadir setiap bulannya dengan cara a) Melalui media telekomunikasi dengan cara SMS untuk mengingatkan keluarga atau lansia. b) Memeberikan bubur kacang ijo atau makanan ringan lainnya agar lansia tertarik untuk datang ke posyandu lansia. c) Kader dapat membuat arisan bagi para lansia 
agar peningkatan kunjungan pelayanan Posyandu lansia di Desa Suakaraya Kecamatan Pancurbatu meningkat

4. Memberikan informasi kepada para tokoh masyarakat dan pihak yang berkepentingan di Desa Sukaraya agar memberikan fasilitas serta dukungan terusmenurus, memebrikan informasi tentang pentingnya posyandu lansia bagi masyarakat

\section{Hasil dan Pembahasan}

Pengabdian Kepada Masyarakat ini memberikan dampak yang sangat signifikan ke pada mitra. diantaranya adalah:

1. Para keluarga lansia kurang memiliki pengetahuan terhadap pentingnya kesehatan bagi lansia. Keluarga jadi bersedia unutk mengantar jemput lansia di posyandu lansia. Dengan sehatnya lansia tidak menganggu pekerjaan dari keluarga lansia sendiri.

2. Para lansia setelah mendapat penyuluhan dapat mengerti dengan baik dari manfaat posyandu lansia, yang selama ini dibenaknya tergambar hanya sekedar timbang badan. Namun setalah mengikuti penyuluhan, lansia ini dapat memahami lebih lengkap manfaat posyandu lansia.

3. Kader posyandu yang selama ini memberikan pelayanan kepada lansia sekedarnya, dapat berubah dengan baik dengan memberikan promosi secara inovatif.

4. Tanggungjawab tokoh masyarakat, perangkat desa serta pemangku kepentingan yang ada di Desa Sukaraya untuk meberikan dukungan kepada lansia agar bersedia datang ke posyandu lansia semakin baik.

\section{Kesimpulan}

Setelah dilakukan kegiatan Pengabdian Kecapatan Pancurbatu dapat diambil kesimpulan antara lainlain :

1. Lansia menggunakan pelayanan posyandu lansia dan 50\% memanfaatkan pelayanan posyandu lansia.

2. Bahwa Pengetahuan, sikap, dukungan keluarga, dukungan kader berpengaruh sekali terhadap pemanfaatan posyandu lansia. Diperlukan pemahaman yang lebih riil tentang posyandu lansia

3. Dukungan keluarga merupakan hal yang paling besar yang mempengaruhi lansia untuk dapat datang memanfatkan posyandu lansia.

\section{DAFTAR PUSTAKA}

Kemenkes RI.Gambaran Kesehatan Lanjut Usia di Indonesia. Jakarta: 2013.

Tamher S. dan Noorkasiani. Kesehatan Usia Lanjut dengan Pendekatan Asuhan Keperawatan. Jakarta: Salemba Medika; 2011.

United Nations. Economic and Social Council. Report of the United Nations High Commissioner for Human Rights. Substantive session of 2012; Geneva, 23-27 July 2012

Muzakkir. Faktor-Faktor Yang Mempengaruhi Pemanfaatan Posyandu Lansia di Desa Ilekimok Kecamatan Atadei Kabupaten Lembata NTT. Volume 1 Nomor 3Tahun 2012 